\title{
Editorial Note: Soft Computing Techniques and Applications on Multimedia Data Analyzing Systems
}

\author{
Published online: 3 January 2019 \\ (C) Springer Science+Business Media, LLC, part of Springer Nature 2019
}

Multimedia Tools and Applications gratefully acknowledges the editorial work of the scholars listed below on the special issue entitled, "Soft Computing Techniques and Applications on Multimedia Data Analyzing Systems."

Of 150 papers submitted to this issue, 43 were eventually accepted after a stringent peerreview process.

\section{Harry (Haoxiang) Wang (Corresponding Guest Editor)}

GoPerception Laboratory, USA

hw496@goperception.com

Jonathan Evan Arnold

Cornell University, USA

jonathan@goperception.com

\author{
Nuno Maurilio \\ Cornell University, USA \\ nuno@goperception.com
}

Publisher's Note Springer Nature remains neutral with regard to jurisdictional claims in published maps and institutional affiliations 